Tohoku J. exp. Med., 1981, 133, 175-185

\title{
Hexosaminidase $\mathbf{C}$ in Brain Affected by Tay-Sachs Disease
}

\author{
Ryoji Minami, Fukumi Nakamura, Kazuhiko Oyanagi \\ and Tooru NaKao \\ Department of Pediatrics, Sapporo Medical College, \\ Sapporo 060
}

Minami, R., Nakamura, F., Oyanagi, K. and Nakao, T. Hexosaminidase $C$ in Brain Affected by Tay-Sachs Disease. Tohoku J. exp. Med., 1981, 133 (2), 175-185 - Hexosaminidase (Hex) $\mathrm{C}$ could be detected in human brains by DEAE cellulose column chromatography, when $\mathrm{N}$-acetyl- $\beta$-D-glucosaminidase activity was determined at $\mathrm{pH}$ 5.5. In the chromatographic pattern, the peak of Hex C was always higher than that of Hex A in control prenatal brains and conversely lower in postnatal brains. Hex $\mathrm{C}$ was not detected in the brains obtained from two cases of Tay-Sachs disease. In addition, the content of Hex $\mathrm{C}$ in the brains of two other Tay-Sachs cases was lower than that of the control. The observation suggests that the absence or reduction of $\mathrm{Hex} \mathrm{C}$ may have some relation with biochemical defects in Tay-Sachs disease, although Hex $\mathrm{C}$ does not share common subunit structures with Hex A and the role of Hex C with respect to $\mathrm{GM}_{2}$-ganglioside degradation remains unknown yet.- hexosaminidase C; Tay-Sachs disease; DEAE cellulose column chromatography

Hexosaminidase (Hex) in human brain consists of two major components, A and $\mathrm{B}$. In addition, two minor components, $\mathrm{C}$ and $\mathrm{S}$, have been described in brains obtained from normal, Tay-Sachs and Sandhoff diseases (Braidman et al. 1974a; Besley and Broadhead 1976; Beutler and Kuhl 1977; Potier et al. 1979). Hex C differs from Hex A, B and S in various properties; extralysosomal localization, large size of the molecule, neutral $\mathrm{pH}$ optimum, different substrate specificity and absence of immunological relationship (Penton et al. 1975). Therefore, the existence of Hex $\mathrm{C}$ in tissues affected by Tay-Sachs disease has been the subject of various discussions (Hooghwinkel et al. 1972; Poenaru and Dreyfus 1973; Bradiman et al. 1974b; Penton et al. 1975; Van-Cong et al. 1975; Reuser and Galjaad 1976; Swallow et al. 1976).

The present paper concerns with Hex $\mathrm{C}$ activities in brains obtained from four cases of Tay-Sachs disease. In addition, difference in Hex C activity between control prenatal and postnatal brains will be reported.

\section{Materials AND Methods}

Tissue sample

Pathological brain tissues were obtained from a therapeutically aborted fetus (23 weeks of pregnancy) and three patients (a 33-month-old girl, a 34-month-old girl and a 42-

Received for publication, January 7, 1980. 
month-old boy) with Tay-Sachs disease. Control fetal brains between 20 and 24 weeks of gestation were obtained from therapeutic abortions for psychosocial reasons. Control brains between 2 months and 77 years of age were obtained post mortem from patients with no apparent central nervous system disease. All these tissue specimens were immediately frozen after autopsy and stored at $-20^{\circ} \mathrm{C}$ for two months to five years prior to analysis.

Enzyme preparation

Frozen pieces of brain were homogenized in 5-20 volumes of ice-cold deionized water. The homogenate was sonicated for $1 \mathrm{~min}$ (Branson, Sonifier, Cell Disruptor 200), then centrifuged at $100,000 \times \mathrm{g}$ for $60 \mathrm{~min}$. The supernatant was used as enzyme source.

Enzyme assay

Hex activity was determined using 4-methylumbelliferyl (4MU)-2-acetamido-2-deoxy$\beta$-D-glucopyranoside (4MU-glucosaminide) and -galactopyranoside (4MU-galactosaminide) (Hooghwinkel et al. 1972) (Koch-Light Laboratories, Ltd.). PH optima were examined with the reaction mixtures consisting of $0.1 \mathrm{ml}$ of $0.1 \mathrm{M}$ citrate-phosphate buffer of varied $\mathrm{pH}, 0.1 \mathrm{ml}$ of enzyme sample containing $0.1 \%$ human serum albumin (Hex activity-free) and $0.4 \mathrm{ml}$ of $1 \mathrm{mM} 4 \mathrm{MU}$-glucosaminide or $0.5 \mathrm{mM} 4 \mathrm{MU}$-galactosaminide. The reaction was stopped by the addition of $3 \mathrm{ml}$ of $0.25 \mathrm{M}$ glycine buffer, $\mathrm{pH} \mathrm{10.7.} \mathrm{Fluorescence} \mathrm{was}$ read immediately with a Hitachi spectrophotofluorometer (Model MPF-4) with an excitation wavelength $365 \mathrm{~nm}$, emission wavelength $450 \mathrm{~nm}$. Protein was assayed according to the method of Lowry et al. (1951).

Ion exchange chromatography

Whatman DEAE cellulose (Type DE-52) was equilibrated in $10 \mathrm{mM}$ citrate-phosphate buffer, pH 6.0 and packed in a column $(1.0 \times 10.0 \mathrm{~cm})$. After the sample $(1.0 \mathrm{ml}$ of enzyme preparation) was applied to the column, the column was washed with $60 \mathrm{ml}$ of the equilibration buffer and then eluted with a linear $\mathrm{KCl}$ gradient $(0-0.2 \mathrm{M})$ in $120 \mathrm{ml}$ of the same buffer. Fractions of $3.0 \mathrm{ml}$ were collected at a flow rate of $50 \mathrm{ml} / \mathrm{hr}$. Chromatography was carried out at $4^{\circ} \mathrm{C}$. Each fraction was assayed for Hex activity as follows: $0.1 \mathrm{ml}$ of the fraction was incubated with $0.5 \mathrm{ml}$ of $0.8 \mathrm{mM} 4 \mathrm{MU}$-glucosaminide in $0.1 \mathrm{M}$ citrate-phosphate buffer at $\mathrm{pH} 4.5$ and 5.5 for $60 \mathrm{~min}$.

Concanavalin (Con) A-Sepharose affinity chromatogrqphy

Samples of control and Tay-Sachs brains $(0.5 \mathrm{ml}$ of enzyme preparation) were applied to a column $(1 \times 5 \mathrm{~cm})$ of Con A-Sepharose according to the method of Swallow et al. (1976). After sample application, the column was washed with $15 \mathrm{ml}$ of $0.1 \mathrm{M}$ acetate buffer, pH 6.0 containing $1 \mathrm{M} \mathrm{NaCl}, 0.01 \mathrm{M} \mathrm{MnCl}_{2}, 0.01 \mathrm{M} \mathrm{CaCl}_{2}, 0.01 \mathrm{M} \mathrm{MgCl}$ and then eluted with $30 \mathrm{ml}$ of $0.5 \mathrm{M}$ methyl- $\boldsymbol{\alpha}$-D-mannoside dissolved in the above buffer. Fractions of $3.0 \mathrm{ml}$ were collected at a flow rate of $14 \mathrm{ml} / \mathrm{hr}$. Chromatography was carried out at room temperature. Each fraction was assayed for Hex activity as mentioned above.

\section{Electrophoresis}

Horizontal starch-gel electrophoresis was carried out as described by Swallow et al. (1976). The gel was prepared from one thirtieth dilution of bridge buffer $(0.22 \mathrm{M}$ tris and $0.086 \mathrm{M}$ citric acid) containing $11 \%$ starch and adjusted to $\mathrm{pH} 5.7$. Samples were inserted into the gel using a small piece of filter paper and electrophoresis was performed at $30 \mathrm{~V} / \mathrm{cm}$ for $4 \mathrm{hr}$ at $4^{\circ} \mathrm{C}$.

Staining

Hex was located using $4 \mathrm{MU}$-glucosaminide as substrate which was dissolved in $0.1 \mathrm{M}$ citrate-phosphate buffer, pH 5.5. The product was visualized under ultraviolet light (Swallow et al. 1976).

\section{Results}

\section{Ion exchange chromatography}

DEAE cellulose column chromatography of the samples from control brains showed two major isoenzymes (Hex B and A), when $\mathrm{N}$-acetyl- $\beta$-D-glucosaminidase 


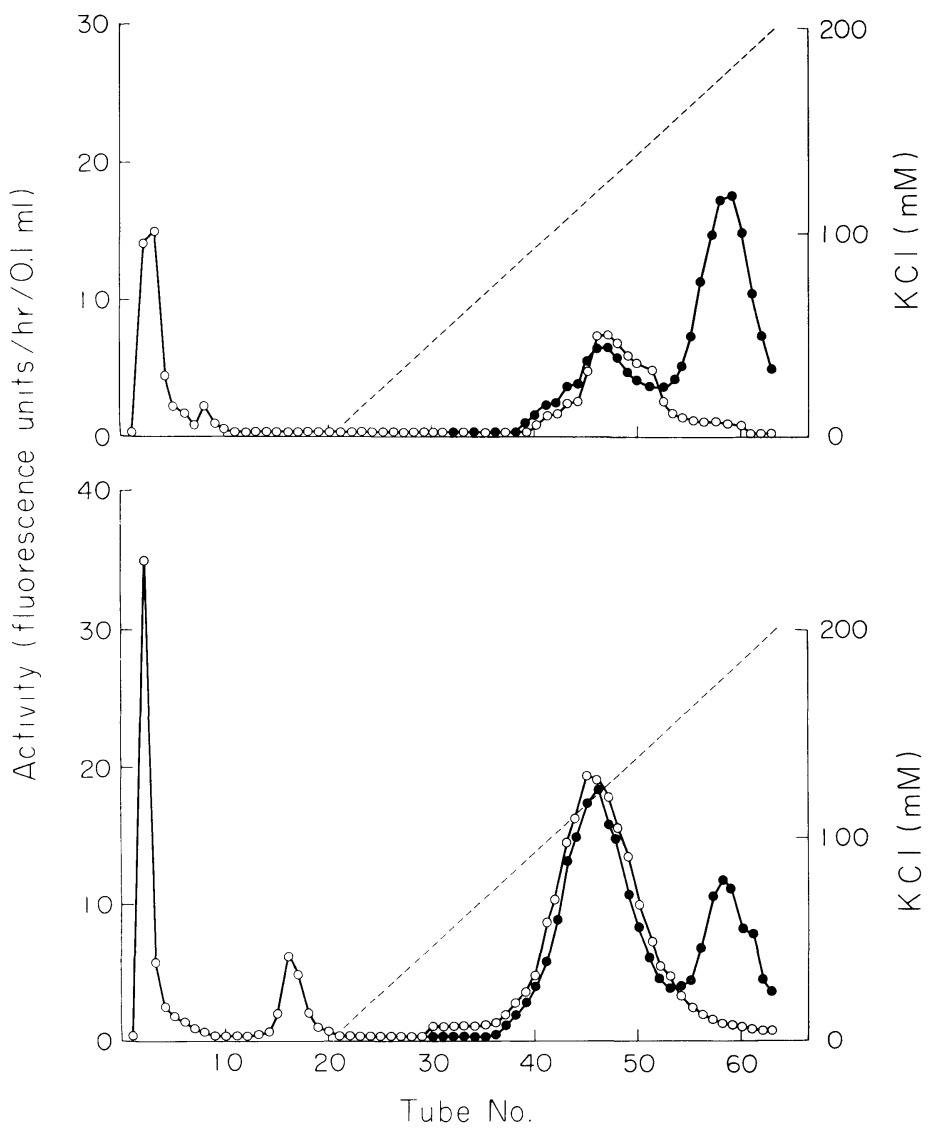

Fig. 1. Fractionation of hexosaminidase isoenzymes in the control brains by DEAE cellulose column chromatography. Upper: 20 weeks of pregnancy. Lower: 2 months old. The plotted relative activities were the fluorescence values. N-Acetyl- $\beta$-Dglucosaminidase activity was measured at $\mathrm{pH} 4.5(\mathrm{\circ})$ and $\mathrm{pH} 5.5(\bullet)$.

was assayed at $\mathrm{pH}$ 4.5. On the other hand, another peak was found in a fraction which was eluted at higher salt concentration than that required for Hex A, when the assay was carried out at pH 5.5 (Figs. 1, 2). The third peak was always higher than that of Hex A in the prenatal brains derived from various gestation ages examined and, on the contrary, always lower in the postnatal brains. The elution profiles for the Tay-Sachs brains were shown in Figs. 3 and 4. The third peak was absent in the elution profiles for the brains obtained from fetal Tay-Sachs disease and a case of Tay-Sachs disease. The amounts of Hex A, B and the third peak component in the control and Tay-Sachs brains were calculated on the basis of total fluorescence activity of respective Hex peak areas of the eluate fractions. In the two Tay-Sachs brains, in which the third peak was present, the ratio of the amount of the third peak component to those of the other peak components was found to be lower than in the control brains. 


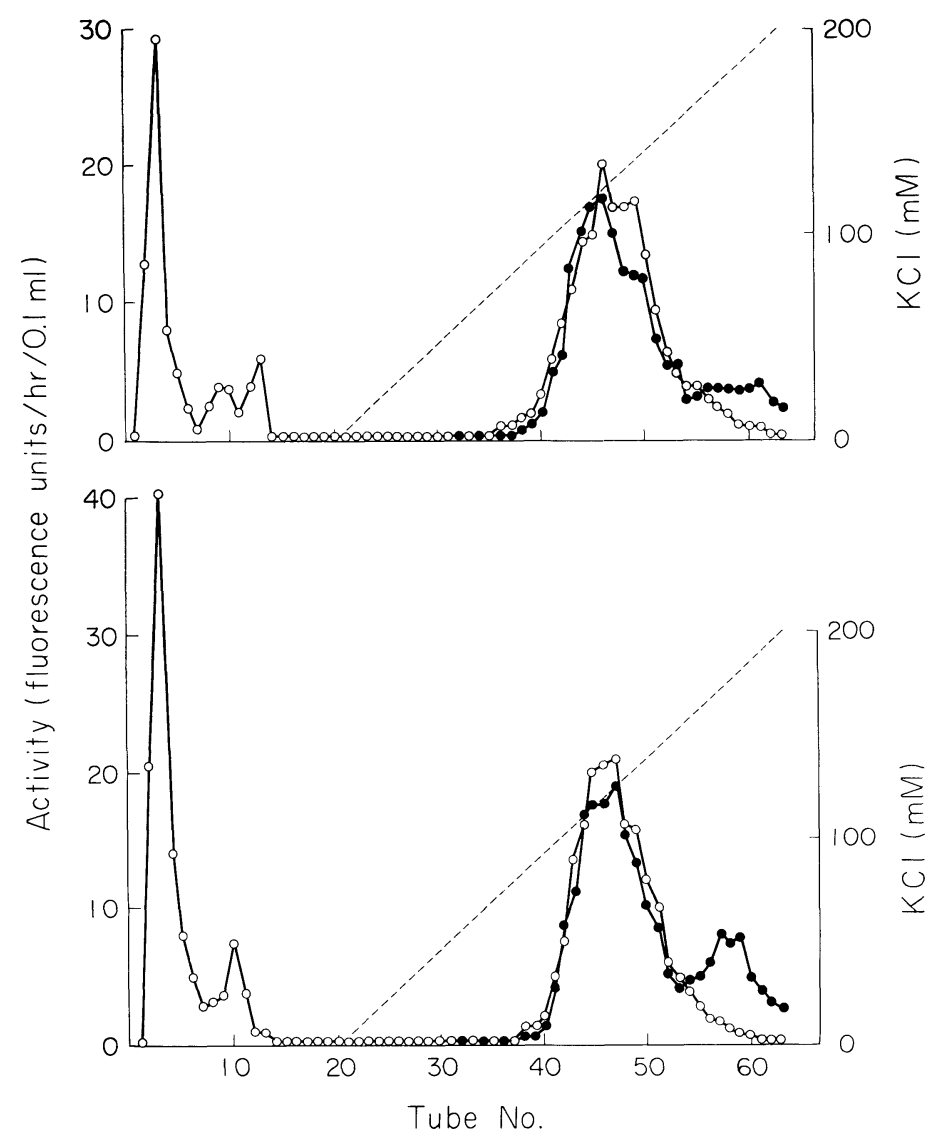

Fig. 2. Fractionation of hexosaminidase isoenzymes in the control brains by DEAE cellulose column chromatography. Upper: 8 years old. Lower: 77 years old. The plotted relative activities were the fluorescence values. $\mathrm{N}$-Acetyl- $\beta$-D-glucosaminidase activity was measured at $\mathrm{pH} 4.5(\mathrm{\circ})$ and $\mathrm{pH} 5.5(\bullet)$.

\section{Con A-Sepharose affinity chromatography}

Column chromatography on Con A-Sepharose revealed that more than $50 \%$ of total $\mathrm{N}$-acetyl- $\beta$-D-glucosaminidase activity in the control fetal brain as assayed at $\mathrm{pH} 5.5$ was unbound to Con A-Sepharose, while almost all of the activity in fetal Tay-Sachs brain was bound to Con A-Sepharose (Fig. 5). Swallow et al. (1976) had confirmed the binding of Hex A and B to Con A-Sepharose, and unbinding of Hex C. The Hex $\mathrm{C}$ from fetal brain which remained unbound to Con A-Sepharose was again chromatographed on DEAE cellulose column. As shown in Fig. 6 a small peak of $\mathrm{N}$-acetyl- $\beta$-D-glucosaminidase as assayed at $\mathrm{pH} 4.5$, was observed at the same salt concentration as required to elute a large peak as assayed at $\mathrm{pH}$ 5.5. Therefore, the peak detected by assay of $\mathrm{N}$-acetyl- $\beta$-D-glucosaminidase at $\mathrm{pH} 5.5$ on DEAE cellulose column chromatography was identified as Hex C. 


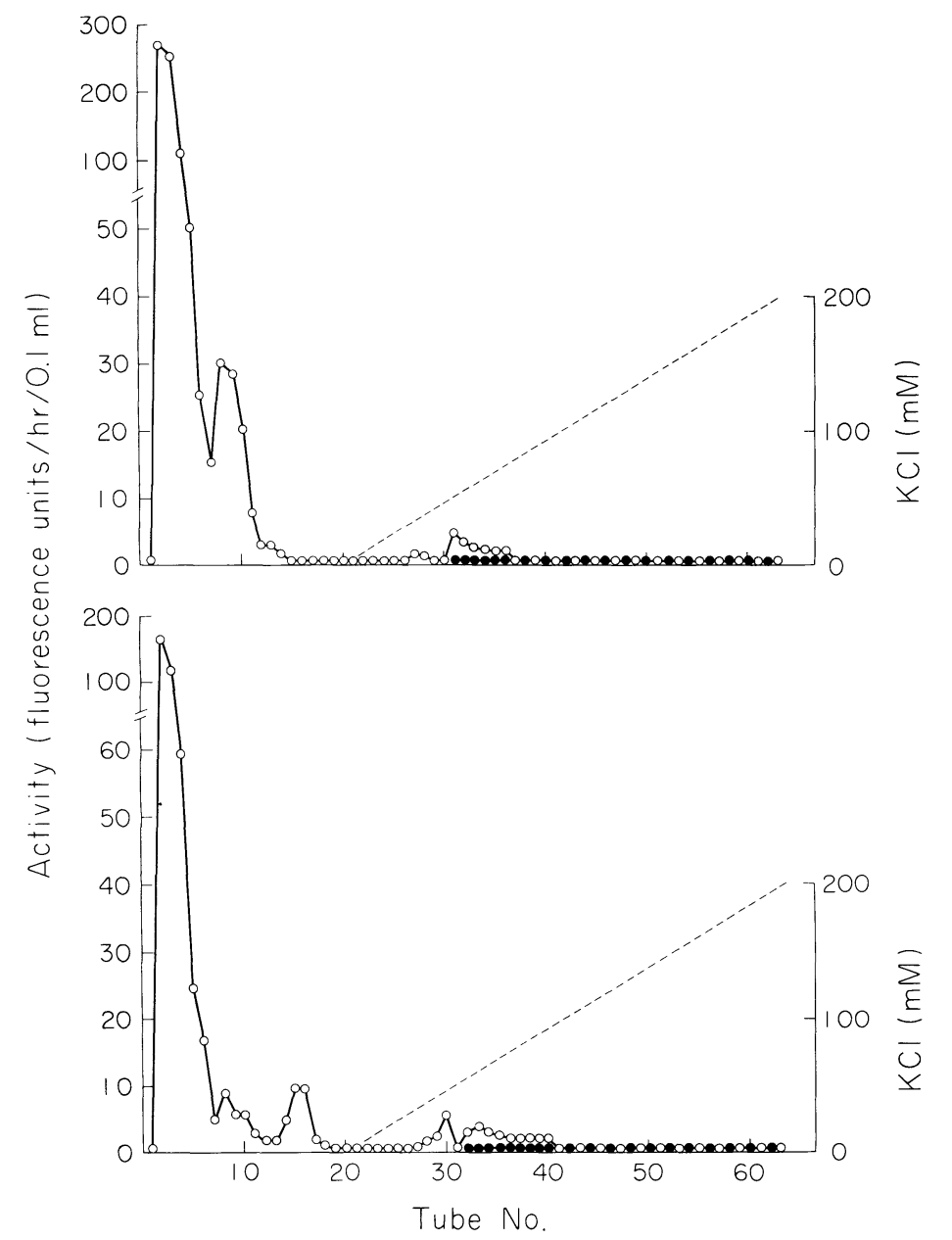

Fig. 3. Fractionation of hexosaminidase isoenzymes in the brains obtained from Tay-Sachs disease by DEAE cellulose column chromatography. Upper: 23 weeks of pregnancy. Lower: 33 months old. The plotted relative activities were the fluorescence values. $\mathrm{N}$-Acetyl- $\beta$-D-glucosaminidase activity was measured at $\mathrm{pH} 4.5(\mathrm{O})$ and $\mathrm{pH} 5.5(\bullet)$.

\section{Electrophoresis}

When stained at $\mathrm{pH}$ 5.5. with 4MU-glucosaminide, a large amount of Hex C was found in fetal brain and a lesser amount of Hex C in child brain (Fig. 7). Prenatal brain had a higher level of Hex $\mathrm{C}$ than postnatal brain when examined by electrophoresis. This observation is consistent with the data of DEAE cellulose column chromatography.

\section{Properties of Hex $A, B$ and $C$ in the fetal brain}

Individual peak fractions on DEAE and Con A-Sepharose chromatographies of the fetal brain sample were pooled separately and dialyzed against deionized 


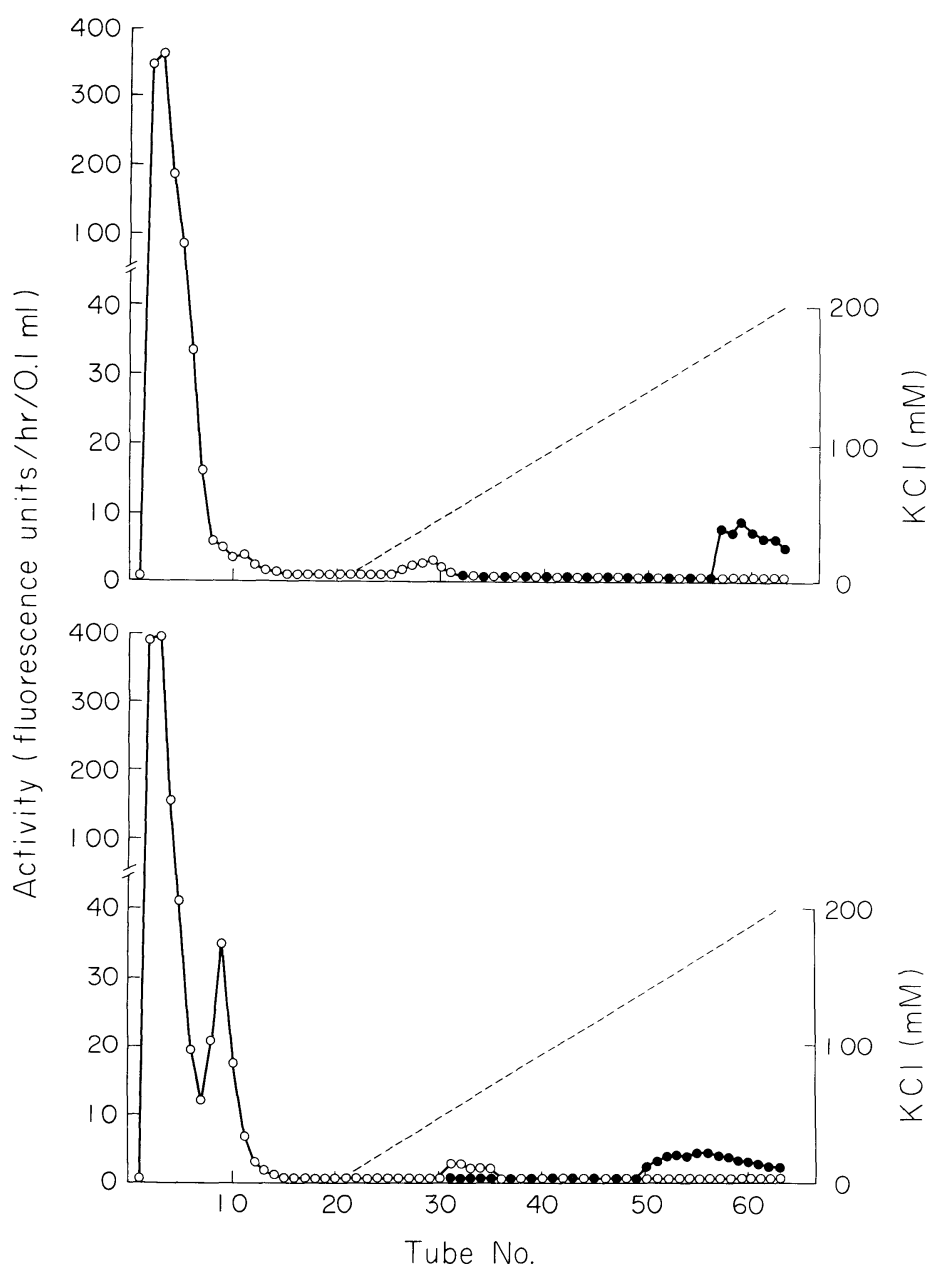

Fig. 4. Fractionation of hexosaminidase isoenzymes in the brains obtained from TaySachs disease by DEAE cellulose column chromatography. Upper: 34 months old. Lower: 42 months old. The plotted relative activities were the fluorescence values. $\mathrm{N}$-Acetyl- $\beta$-D-glucosaminidase activity was measured at $\mathrm{pH} 4.5(\mathrm{O})$ and $\mathrm{pH} 5.5(\bullet)$.

water overnight at $4^{\circ} \mathrm{C}$, then lyophilized. After lyophilization, each component was dissolved in a small volume of ice-cold deionized water. An optimal $\mathrm{pH}$ for Hex C from both chromatographies showed 5.5 with 4MU-glucosaminide (Fig. 8); this disagrees with the previous report (Penton et al. 1975). Hex $\mathrm{C}$ showed a markedly lower activity toward 4MU-galactosaminide as compared with $\mathrm{Hex} \mathrm{A}$ and $\mathrm{B}$.

Total Hex activities of the brains obtained from controls and Tay-Sachs diseases

$\mathrm{N}$-Acetyl- $\beta$-D-glucosaminidase activity was assayed with $10-20 \mu \mathrm{g}$ protein of the enzyme sample and $\mathrm{N}$-acetyl- $\beta$-D-galactosaminidase, with $20-40 \mu \mathrm{g}$ protein. Total N-acetyl- $\beta$-D-glucosaminidase activities of the postnatal brains at both $\mathrm{pH}$ 


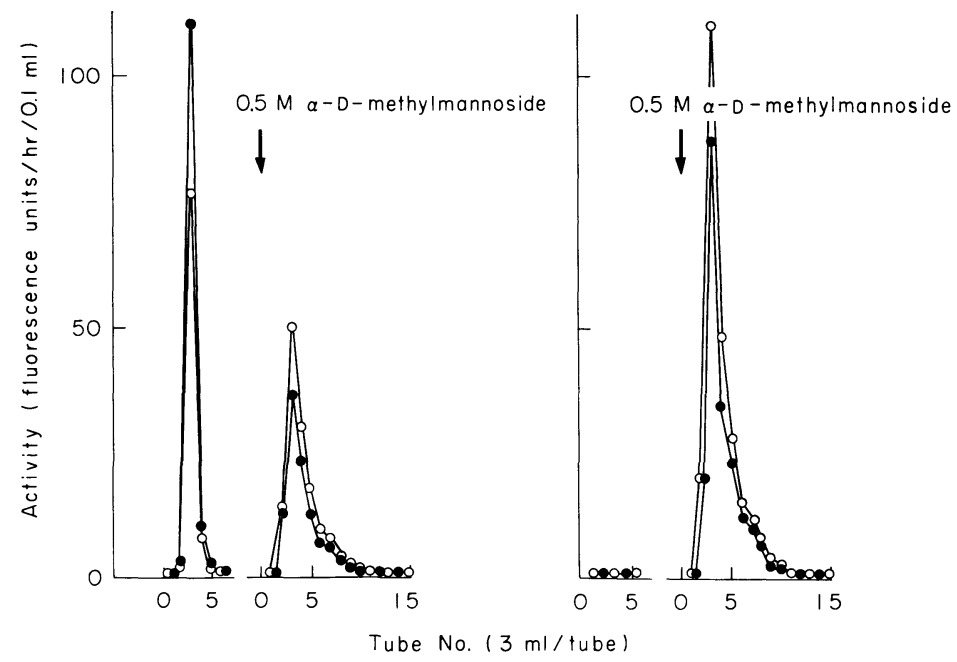

Fig. 5. Con A-Sepharose affinity chromatography of brain hexosaminidase from the control fetus and the fetus with Tay-Sachs disease. Left: Control, 24 weeks of pregnancy. Right: Tay-Sachs disease, 23 weeks of pregnancy. The plotted ralative activities were the fluorescence values. N-Acetyl- $\beta$-D-glucosaminidase activity was measured at $\mathrm{pH} 4.5$ (०) and $\mathrm{pH} 5.5(\bullet)$.

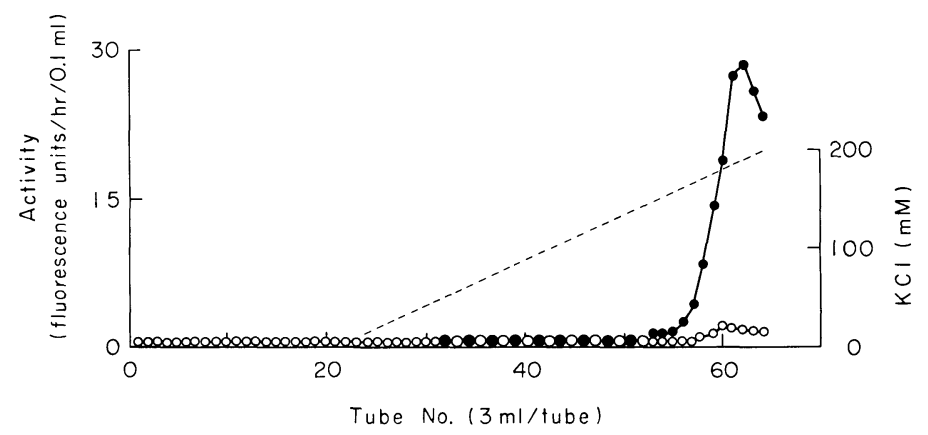

Fig. 6. DEAE cellulose column chromatography of hexosaminidase (Hex C) unbound to Con A-Sepharose prepared from control fetal brain.

The plotted relative activities were the fluorescence values. N-Acetyl- $\beta$-D-glucosaminidase activity was measured at $\mathrm{pH} 4.5(\mathrm{O})$ and $\mathrm{pH} 5.5(\bullet)$.

4.5 and 5.5 were larger than those of the prenatal brains and the ratios of the activities at $\mathrm{pH} 5.5$ and 4.5 in the postnatal brains were smaller than those in the prenatal brains (Fig. 9). Tay-Sachs displayed the increased activities. In contrast to the cases of the control fetal brain, however, $\mathrm{N}$-acetyl- $\beta$-D-glucosaminidase activity at $\mathrm{pH}$ 5.5. was smaller than that at $\mathrm{pH} 4.5$ in the fetal Tay-Sachs brain. 


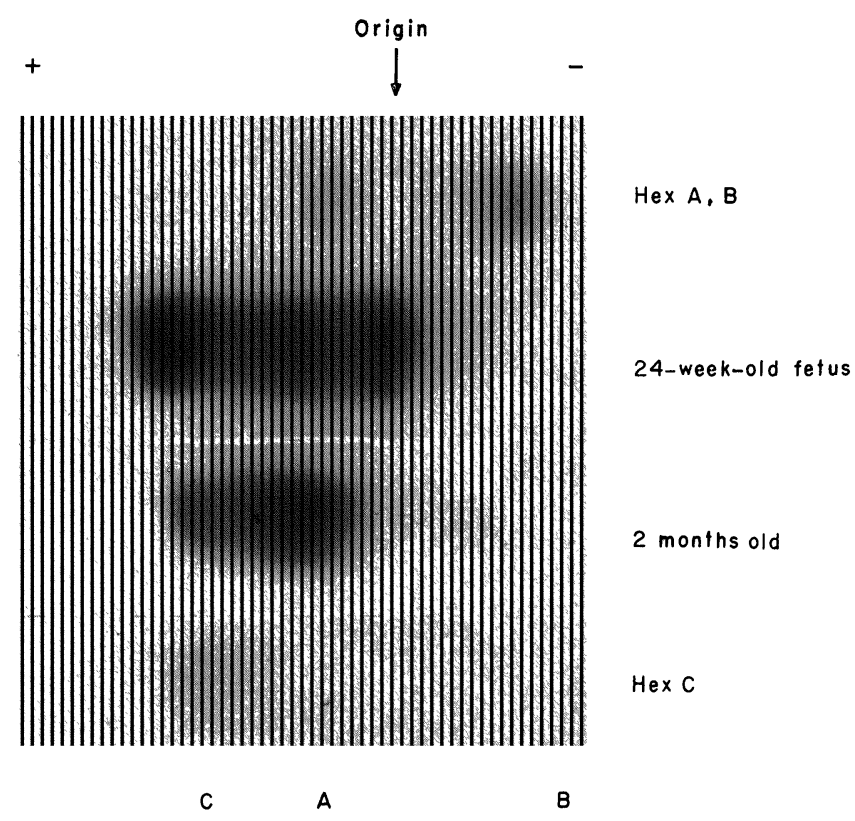

Fig. 7. Starch gel electrophoresis of $\mathrm{N}$-acetyl- $\beta$-D-glucosaminidase at $\mathrm{pH} 5.5$ in the brain extracts.

Hex A, B and C were prepared from DEAE cellulose column chromatography of the fetal brain.

\section{Discussion}

Hex C was first observed in human brain tissues by Hooghwinkel et al. (1972). Thereafter, Hex C has been separated from Hex A and B using electrophoresis. A few papers (Braidman et al. 1974a; Overdijk et al. 1975) reported that Hex C could not be separated by ion exchange chromatography on DEAE cellulose, because Hex $\mathrm{C}$ appeared to undergo some change under this condition. In the present study, Hex C could be separated from Hex A and B by DEAE cellulose column chromatography.

The peak of Hex $\mathrm{C}$ in the elution profile was higher than that of the Hex A in the prenatal brains and lower in the postnatal brains. Poenaru and Dreyfus (1973) also showed by electrophoresis that Hex C in extracts from embryonic tissues was more abundant than that from adult tissues. On the other hand, Hex $\mathrm{S}$, which is one of the minor components of Hex isoenzymes, could not be detected in the control or Tay-Sachs brains as reported by Beutler and Kuhl (1977).

The existence of Hex $\mathrm{C}$ in tissues affected by Tay-Sachs disease has only been discussed (Hooghwinkel et al. 1972; Poenaru and Drefyus 1973; Braidman et al. 1974b; Penton et al. 1975; Van-Cong et al. 1975; Reuser and Galjaad 1976; Swallow et al. 1976), because it is difficult to separate Hex C from Hex S by electrophoresis and Hex C activity appears to be highly labile while Hex A and B are quite stable (Poenaru and Dreyfus 1973; Penton et al. 1975). We have experienced, however, 


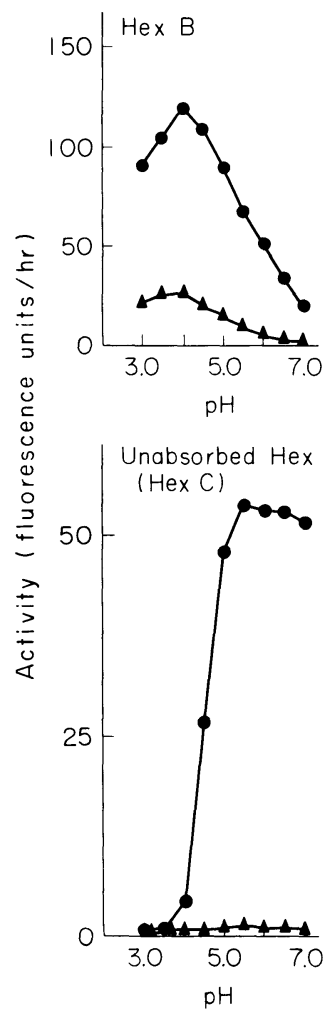

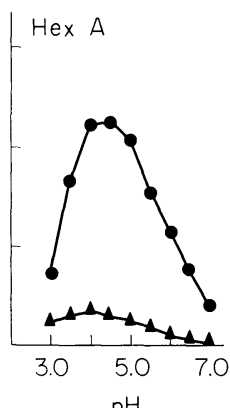

$\mathrm{pH}$

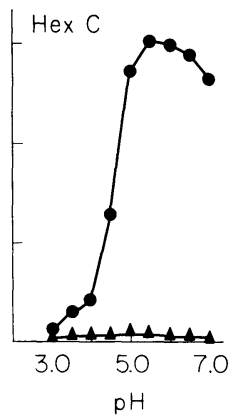

Absorbed Hex

(Hex $A$ and $B$ )

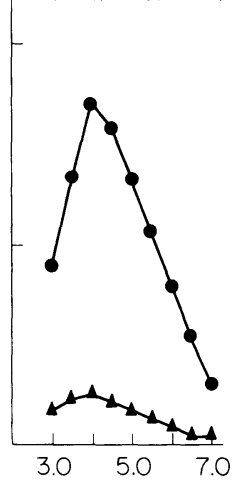

$\mathrm{pH}$

Fig. 8. pH activity profiles of hexosaminidase components prepared from the control fetal brain.

Upper: pH activity profiles of hexosaminidase A, B and $\mathrm{C}$ prepared from DEAE cellulose column chromatography.

Lower: $\mathrm{pH}$ activity profiles of Hex absorbed and unabsorbed in Con A-Sepharose.

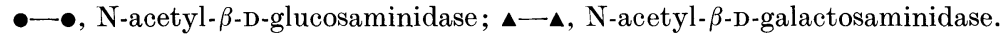

that Hex C was stable for 6 months when stored at $-70^{\circ} \mathrm{C}$. Hex $\mathrm{C}$ was not detected in the brains obtained from two cases of Tay-Sachs disease. Also, the amount of Hex $\mathrm{C}$ in the brains of two other Tay-Sachs cases were lower than that of the control. Hex C was absent in the fetal Tay-Sachs brain, whereas a considerable amount of Hex C was present in all the control fetal brains examined. It is of interest to note that clinically the Tay-Sachs patient without Hex C activity had more trouble in seizures as compared with the Tay-Sachs patients with Hex C activity, although there was no difference between $\mathrm{GM}_{2}$-ganglioside accumulation in their brains (unpublished data).

Hex $\mathrm{C}$ seems to play a more important role in prenatal brain than in postnatal brain. Also no or diminished Hex $\mathrm{C}$ activity may represent a characteristic of the Tay-Sachs disease, although the role of Hex $\mathrm{C}$ in relation to $\mathrm{GM}_{2}$-ganglioside degradation remains as yet unknown and $\operatorname{Hex} \mathrm{C}$ is different genetically and structurally from Hex A. 

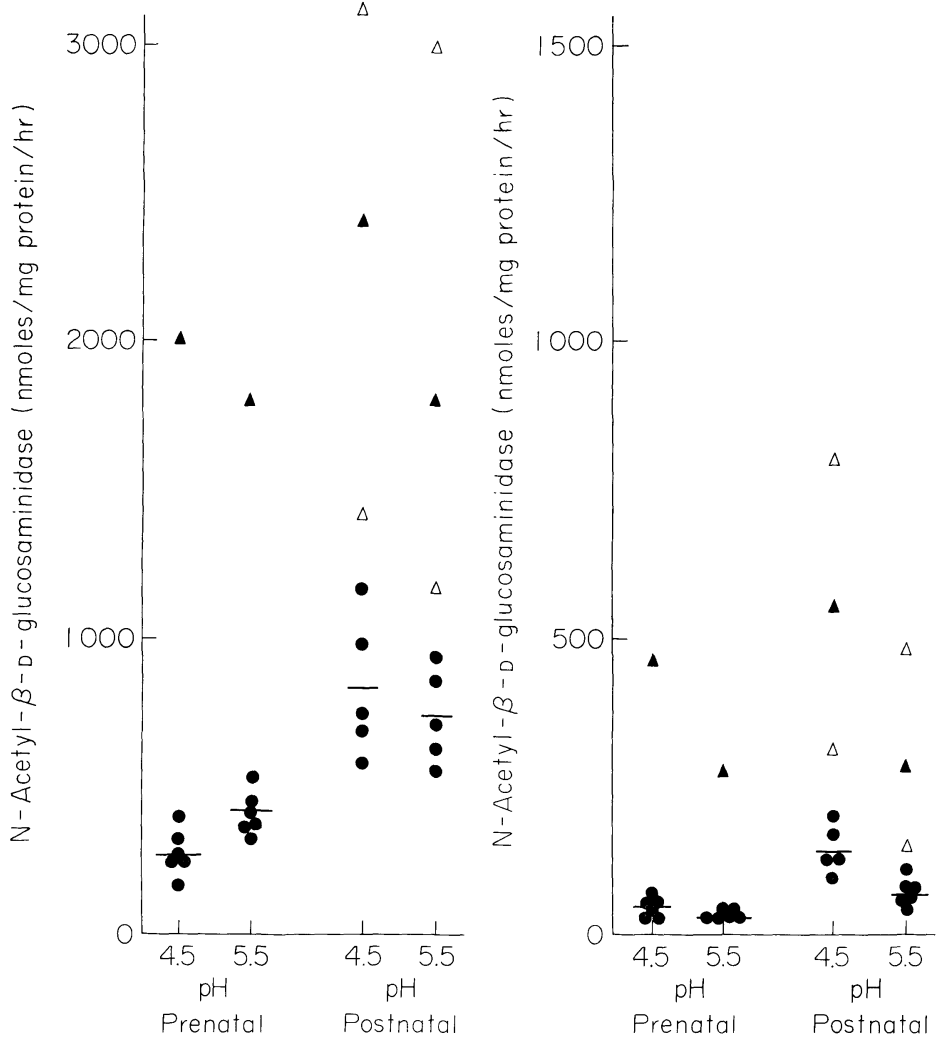

Fig. 9. Activities of hexosaminidase in the brains obtained from control individuals and patients with Tay-Sachs disease ( 2 months to 8 years of age). Activities were measured with $0.1 \mathrm{M}$ citrate-phosphate buffer at $\mathrm{pH} \mathrm{4.5}$ and 5.5.

•, control individuals; $\Delta$, Tay-Sachs patients with Hex C activity; $\Delta$, Tay-Sachs patients without Hex $\mathrm{C}$ activity.

\section{Acknowledgments}

Thanks are due to Dr. S. Higami, Department of Pediatrics, School of Medicine, Osaka City University, for the generous supply of specimens which enabled us to carry out the present study.

\section{References}

1) Besley, G.T.N. \& Broadhead, D.M. (1976) Studies on human N-acetyl- $\beta$-D-hexosaminidase C separated from neonatal brain. Biochem. J., 155, 205-208.

2) Beutler, E. \& Kuhl, W. (1977) The tissue distribution of hexosaminidase S and hexosaminidase C. Ann. hum. Genet., 41, 163-167.

3) Braidman, I., Carroll, M., Dance, N. \& Robinson, D. (1974a) Separation and properties of human brain hexosaminidase C. Biochem. J., 143, 295-301.

4) Braidman, I., Carrool, M., Dance, N., Robinson, D., Poenaru, L., Weber, A., Dreyfus, J.C., Overdijk, B. \& Hooghwinkel, G.J.M. (1974b) Characterization of human Nacetyl- $\beta$-hexosaminidase C. FEBS Lett., 41, 181-184.

5) Hooghwinkel, G.J.M., Veltkamp, W.A., Overdijk, B. \& Lisman, J.J.W., (1972) Electrophoretic separation of $\beta-\mathrm{N}$-acetylhexosaminidases of human and bovine brain 
and liver and of Tay-Sachs brain tissue. Hoppe-Seylers Z. physiol. Chem., 353, 839841.

6) Lowry, O.H., Rosebrough, N.J., Farr, A.L. \& Randall, R.J. (1951) Protein measurement with the Folin phenol reagent. J. biol. Chem., 193, 265-275.

7) Overdijk, B., Van Der Koef, W.M.J., Veltkamp, W.A. \& Hooghwinkel, G.J.M. (1975) The separation of bovine brain $\beta$-N-acetyl-D-hexosaminidases. Biochem. J., 151, 257-261.

8) Penton, E., Poenaru, L. \& Dreyfus, J.C. (1975) Hexosaminidase C in Tay-Sachs and Sandhoff disease. Biochim. biophys. Acta, 391, 162-169.

9) Poenaru, L. \& Dreyfus, J.C. (1973) Electrophoretic study of hexosaminidase C. Clin. chim. Acta, 43, 439-442.

10) Potier, M., Teitelbaum, J., Melancon, S.B. \& Dallaire, L. (1979) Purification and some properties of liver and brain $\beta$-N-acetyl-hexosaminidase S. Biochim. biophys. Acta, 566, 80-87.

11) Reuser, A.J.J. \& Galjaad, H. (1976) Characterization of $\beta$-D-N-acetylhexosaminidase $\mathrm{C}$ and $\mathrm{S}$ in fibroblasts from control individuals and patients with Tay-Sachs disease. FEBS Lett., 71, 1-5.

12) Swallow, D.M., Evans, L., Saha, N. \& Harris, H. (1976) Characterization and tissue distribution of $\mathrm{N}$-acetylhexosaminidase $\mathrm{C}$ : Suggestive evidence for a separate hexosaminidase locus. Ann. hum. Genet., 40, 55-66.

13) Van-Cong, N., Weil, D., Rebourcet, R. \& Frezal, J. (1975) A study of hexosaminidases in interspecific hybrids and in $\mathrm{GM}_{2}$ gangliosidosis with a discussion on their genetic control. Ann. hum. Genet., 39, 111-123. 